\title{
Forming of ecological awareness of the students of international relations and regional studies at the English language teaching
}

\author{
Zhanna Konovalova*, Alsu Khafizova, and Natalia Arzhantseva \\ Kazan Federal University, Department of foreign languages in the sphere of international relations, \\ 420008 Kazan, Russia
}

\begin{abstract}
The paper analyses methodology of forming ecological awareness of the students of international relations and regional studies at higher educational level. The pedagogical experience of Kazan Federal University is presented. The authors justify the topicality of implementing ecology and climate change related topics in the syllabus of the educational programmes. The systemic approach to the formation of ecological literacy is implemented throughout the whole course of the Bachelor degree programme. The authors of the article conduct a survey to define the students' level of ecological awareness and present different approaches to implementing climate change and other environmental issues in the foreign language teaching process, including discussions, dialogues, brainstorming, problem-solution role-playing, project presentation, and writing an essay.
\end{abstract}

\section{Introduction}

In recent years the global community has witnessed the apparent deterioration of the ecological situation in terms of climate change, reduction of biodiversity, global degradation of fresh water supply, severe pollution of air and soil, exhaustion of non-renewable resources, to name just a few. It has led to further understanding of the importance of shaping new approaches to the relationship of men and nature. As some scholars argue, governments, organizations, businesses and individuals are becoming alarmed but also seeking actionable solutions, goals and strategies aimed at alleviating the situation [1]. One of the approaches is consistent with the conception of sustainable development of nature and society which is based on the theory of co-evolution and which allows people to rethink their nature and role in the biosphere [2]. The concepts of "shallow ecology", including the anthropocentric idea that man has unlimited right to use nature resources, have gradually been giving way to the principles of "deep ecology" coined by A. Naess and G. Sessions in 1970-s, which include rejection of the idea of anthropocentrism as opposed to biocentric equality, variety and symbiosis, and give rise to the concept of ecological consciousness [3]. Ecological consciousness is treated as a multi-component phenomenon represented by environmental attention, environmental memory; environmental perception, environmental affect;

* Corresponding author: zhanna.konovalova@gmail.com 
environmental thinking; and environmental will [4]. The functions of ecological consciousness include environmental goal-setting; environmental planning (knowledge); environmental forecasting and programming; environmental attitude; environmental awareness; environmental assessment and self-assessment; environmental control and selfmonitoring [5]. Environmental, or ecological awareness is, thus, awareness by the man of $\mathrm{him} /$ herself in the world of nature and his/her qualities .

In recent years global climatic change has been called an environmental problem of potentially devastating proportions and the greatest threat to global security [6]. It attracts attention not only of the ecologists and environmentalists, but of a great variety of specialists including politicians, military, intergovernmental and non-governmental organizations. The formation of ecological awareness of the students who study international relations and regional studies becomes particularly important as these people are going to be future specialists that will deal with many challenges the modern world faces nowadays. The structure of international relations today is gaining a more and more complex format that directly influences the content of the educational process and developing professional discourse of a specialist in the sphere of international relations. That's why including vocationally oriented projects in the process of foreign language teaching, specifically projects related to sustainable development and tackling the problem of climate change facilitates reaching the goal of the formation of students' ecological thinking.

\section{Methods}

The aim of our research is to study the feedback of lower-division $\left(1^{\text {st }}\right.$ and $2^{\text {nd }}$ courses $)$ and upper-division $\left(3^{\text {rd }}\right.$ and $4^{\text {th }}$ courses) students, who do Bachelor programmes in international relations and regional studies at Kazan Federal University to the problem of climate change and environment. For this purpose, we designed the questionnaire and asked the students to fill it in. The questionnaire framework aimed to determine the students' level of ecological awareness in terms of self-reflection, their response to the most acute ecological issues and assessment of the effectiveness of various intergovernmental organizations' activities (see Table 1).

Table 1 Description of the data collection

\begin{tabular}{|l|l|}
\hline \multicolumn{1}{|c|}{ Sample size } & \multicolumn{1}{c|}{ 94 students } \\
\hline $\begin{array}{l}\text { Participants' } \\
\text { educational } \\
\text { background }\end{array}$ & $\begin{array}{l}\text { Bachelor programmes in International Relations and Regional Studies at } \\
\text { Kazan Federal University }\end{array}$ \\
\hline $\begin{array}{l}\text { Participants' } \\
\text { nationality }\end{array}$ & $\begin{array}{l}\text { The students who took part in the research come from Russia, Ukraine, } \\
\text { Kazakhstan, China, Indonesia, Uganda }\end{array}$ \\
\hline Types of questions & 8 closed-ended and 2 open-ended questions \\
\hline $\begin{array}{l}\text { Questions asked to } \\
\text { participants }\end{array}$ & $\begin{array}{l}\text { How would you assess the level of your environmental consciousness? } \\
\text { Are you personally a conscious consumer? } \\
\text { Whose responsibility is it to solve ecological problems? } \\
\text { Do you consider that the problem of climate change is overhyped now? } \\
\text { Is climate change a merely environmental problem? } \\
\text { Are various climate change summits really effective and can bring positive } \\
\text { results? } \\
\text { Are IGO (Intergovernmental organizations) effective in addressing climate } \\
\text { security challenges? } \\
\text { Should traditional security organizations such as NATO and the UN } \\
\text { Security Council deal with climate change? }\end{array}$ \\
\hline
\end{tabular}




\begin{tabular}{|l|l|}
\hline & $\begin{array}{l}\text { Which country has experienced most the negative effects of climate } \\
\text { change? } \\
\text { Which country has gained more success in implementing measures to fight } \\
\text { climate change? }\end{array}$ \\
\hline Research approach & Quantitative method and content-analysis \\
\hline
\end{tabular}

In the present paper we would like to argue the importance of implementing educational material as well as projects related to ecology and climate change in the process of English language teaching throughout the whole course of the Bachelor degree programme in international relations and regional studies. Thus, the experience in this field is presented. Methods that were applied: The principal method of research is testing, which includes the study of ecological awareness level among the students. Other methods used: continuous sampling method and method of content analysis.

\section{Results and discussion}

The main findings from the conducted questionnaire and its in-depth analysis helped to outline the level of ecological awareness and compare it across lower-division and upperdivision university students (see Tables 2 and 3). The responses to the questions formulated in the questionnaire provided information about the student's self-assessment of their environmental consciousness, their understanding of the modern ecological situation and the activities of different organizations in response to environmental challenges.

Table 2 Lower division (1-2 courses) students' responses to questionnaire (\%)

\begin{tabular}{|c|c|c|c|c|c|c|c|}
\hline & Question & $\mathbf{A}$ & 9 & B & $\%$ & C & $\%$ \\
\hline 1 & $\begin{array}{l}\text { How would you assess the } \\
\text { level of your environmental } \\
\text { consciousness? }\end{array}$ & High level & $\begin{array}{c}16 \\
7\end{array}$ & $\begin{array}{l}\text { Average } \\
\text { level }\end{array}$ & 69,4 & $\begin{array}{l}\text { Low } \\
\text { level }\end{array}$ & 13,9 \\
\hline 2 & $\begin{array}{l}\text { Are you personally a } \\
\text { conscious consumer? }\end{array}$ & Yes & 25 & $\begin{array}{c}\text { Rather } \\
\text { yes }\end{array}$ & 52,8 & No & 22,2 \\
\hline 3 & $\begin{array}{c}\text { Whose responsibility is it } \\
\text { to solve ecological } \\
\text { problems? }\end{array}$ & $\begin{array}{c}\text { The } \\
\text { governme } \\
\text { nt's }\end{array}$ & $\begin{array}{c}14, \\
6\end{array}$ & $\begin{array}{c}\text { Specialist } \\
\text { s' }\end{array}$ & 4,8 & $\begin{array}{l}\text { Every } \\
\text { person's }\end{array}$ & 80,6 \\
\hline 4 & $\begin{array}{l}\text { Do you consider that the } \\
\text { problem of climate change } \\
\text { is overhyped now? }\end{array}$ & Yes & $\begin{array}{c}13, \\
1\end{array}$ & No & 71,2 & $\begin{array}{l}\text { I don't } \\
\text { know }\end{array}$ & 15,7 \\
\hline 5 & $\begin{array}{l}\text { Is climate change a merely } \\
\text { environmental problem? }\end{array}$ & Yes & $\begin{array}{c}33 \\
4\end{array}$ & No & 52,7 & $\begin{array}{l}\text { I don't } \\
\text { know }\end{array}$ & 13,9 \\
\hline 6 & $\begin{array}{c}\text { Are various climate } \\
\text { changes summits really } \\
\text { effective and can bring } \\
\text { positive results? }\end{array}$ & Yes & $\begin{array}{c}33, \\
3\end{array}$ & No & 19,4 & $\begin{array}{l}\text { I don't } \\
\text { know }\end{array}$ & 47,3 \\
\hline 7 & $\begin{array}{c}\text { Are IGO } \\
\text { (Intergovernmental } \\
\text { organizations) effective in } \\
\text { addressing climate security } \\
\text { challenges? } \\
\end{array}$ & Yes & $\begin{array}{c}59 \\
4\end{array}$ & No & $8,9^{1}$ & $\begin{array}{l}\text { I don't } \\
\text { know }\end{array}$ & 21,7 \\
\hline 8 & $\begin{array}{l}\text { Should traditional security } \\
\text { organizations such as } \\
\text { NATO and the UN } \\
\text { Security Council deal with } \\
\text { climate change? }\end{array}$ & Yes & $\begin{array}{c}65 \\
7\end{array}$ & No & $3,6^{2}$ & $\begin{array}{l}\text { I don't } \\
\text { know }\end{array}$ & 10,7 \\
\hline
\end{tabular}


Table 3 Upper-division (3-4 courses) students' responses to questionnaire (\%)

\begin{tabular}{|c|c|c|c|c|c|c|c|}
\hline & Question & $\mathbf{A}$ & $\%$ & B & $\%$ & $\mathbf{C}$ & $\%$ \\
\hline 1 & $\begin{array}{l}\text { How would you assess } \\
\text { the level of your } \\
\text { environmental } \\
\text { consciousness? }\end{array}$ & $\begin{array}{l}\text { High } \\
\text { level }\end{array}$ & 25,8 & $\begin{array}{l}\text { Avera } \\
\text { ge } \\
\text { level }\end{array}$ & 70,7 & $\begin{array}{l}\text { Low } \\
\text { level }\end{array}$ & 3,5 \\
\hline 2 & $\begin{array}{l}\text { Are you personally a } \\
\text { conscious consumer? }\end{array}$ & Yes & 25,8 & $\begin{array}{c}\text { Rather } \\
\text { yes }\end{array}$ & 62 & No & 12,2 \\
\hline 3 & $\begin{array}{c}\text { Whose responsibility is it } \\
\text { to solve ecological } \\
\text { problems? }\end{array}$ & $\begin{array}{l}\text { The } \\
\text { governm } \\
\text { ent's }\end{array}$ & 15,8 & $\begin{array}{l}\text { Specia } \\
\text { lists' }\end{array}$ & 9,5 & $\begin{array}{l}\text { Every } \\
\text { person' } \\
\text { s }\end{array}$ & 74,7 \\
\hline 4 & $\begin{array}{c}\text { Do you consider that the } \\
\text { problem of climate } \\
\text { change is overhyped } \\
\text { now? }\end{array}$ & Yes & 46,2 & No & 41,4 & $\begin{array}{l}\text { I don't } \\
\text { know }\end{array}$ & 9,4 \\
\hline 5 & $\begin{array}{l}\text { Is climate change a } \\
\text { merely environmental } \\
\text { problem? }\end{array}$ & Yes & 49,1 & No & 40,6 & $\begin{array}{l}\text { I don't } \\
\text { know }\end{array}$ & 10,3 \\
\hline 6 & $\begin{array}{c}\text { Are various climate } \\
\text { changes summits really } \\
\text { effective and can bring } \\
\text { positive results? }\end{array}$ & Yes & 59,3 & No & 25,4 & $\begin{array}{l}\text { I don't } \\
\text { know }\end{array}$ & 15,3 \\
\hline 7 & $\begin{array}{c}\text { Are IGO } \\
\text { (Intergovernmental } \\
\text { organizations) effective } \\
\text { in addressing climate } \\
\text { security challenges? }\end{array}$ & Yes & 60 & No & 29 & $\begin{array}{l}\text { I don't } \\
\text { know }\end{array}$ & 11 \\
\hline 8 & $\begin{array}{c}\text { Should traditional } \\
\text { security organizations } \\
\text { such as NATO and the } \\
\text { UN Security Council } \\
\text { deal with climate } \\
\text { change? }\end{array}$ & Yes & 73,2 & No & 19,6 & $\begin{array}{l}\text { I don't } \\
\text { know }\end{array}$ & 7,2 \\
\hline
\end{tabular}

The comparison of responses of students to the question concerning their level of environmental consciousness demonstrated that the majority of low-division students and high-division students assess it as "average", however, there is difference in terms of "high level" and "low level" responses (See Fig.1). Approximately twice as many upper-division students compared to low-division students assess their environmental consciousness as "high" and almost four times fewer students of the $3^{\text {rd }}$ and $4^{\text {th }}$ year compared to the younger students indicate low level of their environmental consciousness. 


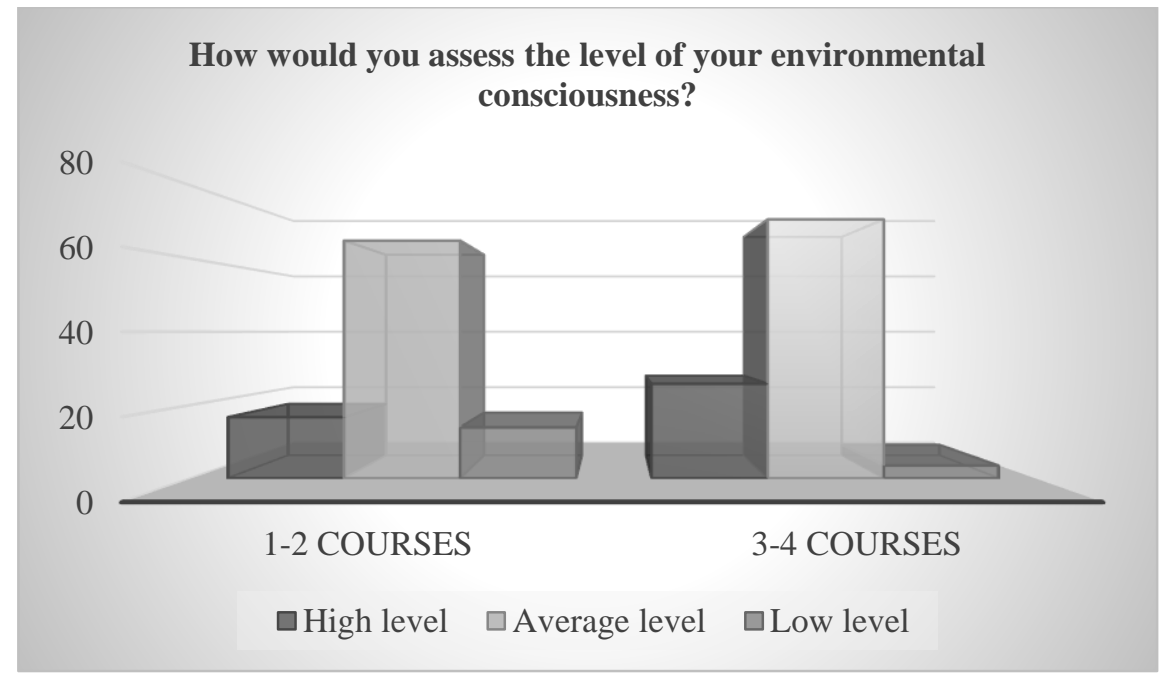

Fig. 1. Self-assessment results of the level of environmental consciousness

The same situation can be observed with student's self-assessment of their consumer habits. More upper-division students perceive themselves as more conscious consumers ("yes" and "rather yes" responses) as compared to lower-division students (See Fig. 2).

\section{Are you personally a conscious consumer?}

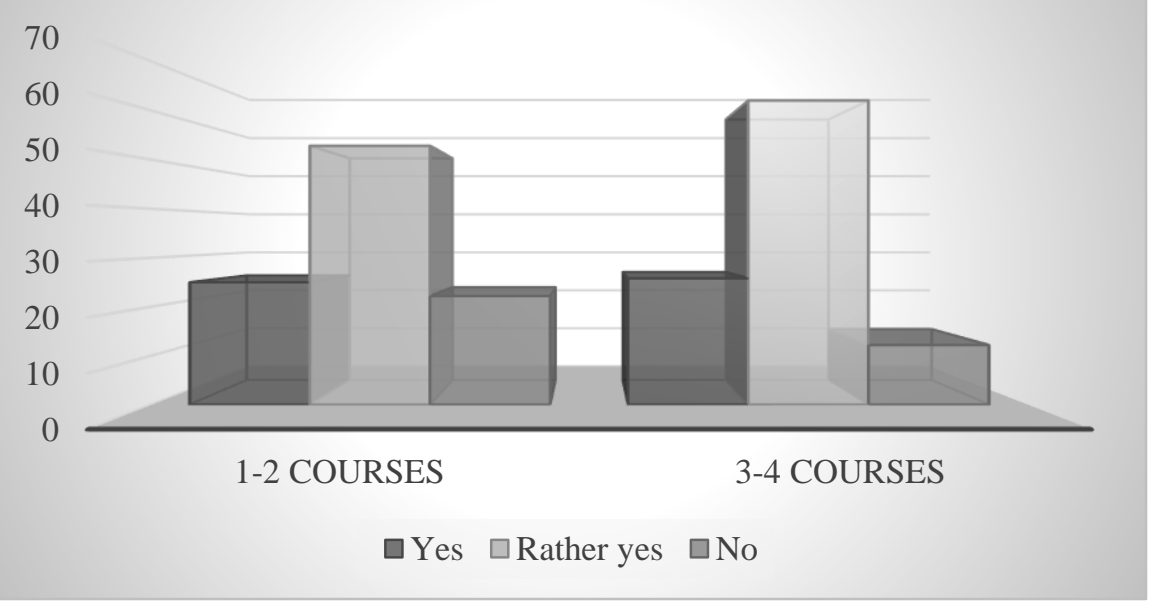

Fig. 2. Self-assessment results of consumer habits

As for the responsibility for solving ecological problems, the majority of all surveyed students outlined the importance of individual actions, the response "every person's" was chosen by $80,6 \%$ of lower-division students and $74,7 \%$ of upper-division students (See Tables 1 and 2). The problem of climate change was assessed by 52,7 \% of lower-division students as not merely an environmental problem, although the responses of $3^{\text {rd }}$ and $4^{\text {th }}$ year students were distributed almost equally $(49,1 \%$ of students treated it as a merely environmental issue and 40,6\% as a more complex one). $71,2 \%$ of lower-division students consider the issue of climate change not to be overhyped, however almost equal number of upper-division students' give both positive and negative responses to the question (46,2\% and $41,4 \%$ respectively). Climate change summits were estimated as efficient by a bigger number of upper-division students (59,3\% compared with 33,3\%). Lower division students 
were less confident in assessment of summits, 47,3\% of them giving "I don't know" response. High level of efficiency of Intergovernmental organizations in addressing climate security challenges was noted by the majority of all students. The opinion that traditional security organizations should deal with climate change prevailed among all categories of students.

The questions 9 and 10 in the questionnaire were open-ended questions and the students had to name the countries which, according to their opinion, experienced most the negative effects of climate change and gained more success in implementing measures to fight it.

According to the data received, both lower-division and upper-division students considered China and Russia to be most adversely affected by climate change, however, two more counties were noted: India ( $1^{\text {st }}$ and $2^{\text {nd }}$ courses $)$ and Japan ( $3^{\text {rd }}$ and $4^{\text {th }}$ courses). The countries that were claimed to be most effective in implementing measures to fight climate change were Sweden and Norway by all students, meanwhile lower-division students also mentioned Japan. Generally, upper-division students seemed to be more well-read and critically thinking which can be proved by the higher general number of countries mentioned and lower number of "I don't know" responses (See Fig. 3 and 4).

Based on the results of the questionnaire, we came to the conclusion that the students of upper-division demonstrated a higher level of environmental awareness both in terms of their self-assessment and responses to the questions concerning various ecological issues and the activities of different organizations aimed at alleviating the problem. One of the factors that led to raising student's ecological consciousness in the course of their Bachelor studies.

The topic of ecology and conservation as well as climate change appears throughout the whole Bachelor degree programme of international relations and regional studies profiles. During the first two courses the syllabus of the English language course in the given context is aimed at developing basic knowledge in the sphere of ecological awareness. At this level of studying students speak about general ecological problems, endangered species and regions, ecological catastrophes. At the lessons of English students cover the issues of tourism and its negative consequences (direct and hidden) on the environment. They propose their solutions of how to minimize the negative impact of tourism and favour sustainable development of the region. The work on these themes is organized in various forms, namely discussions, dialogues, brainstorming, problem-solution role-playing, project presentation, and writing an essay.

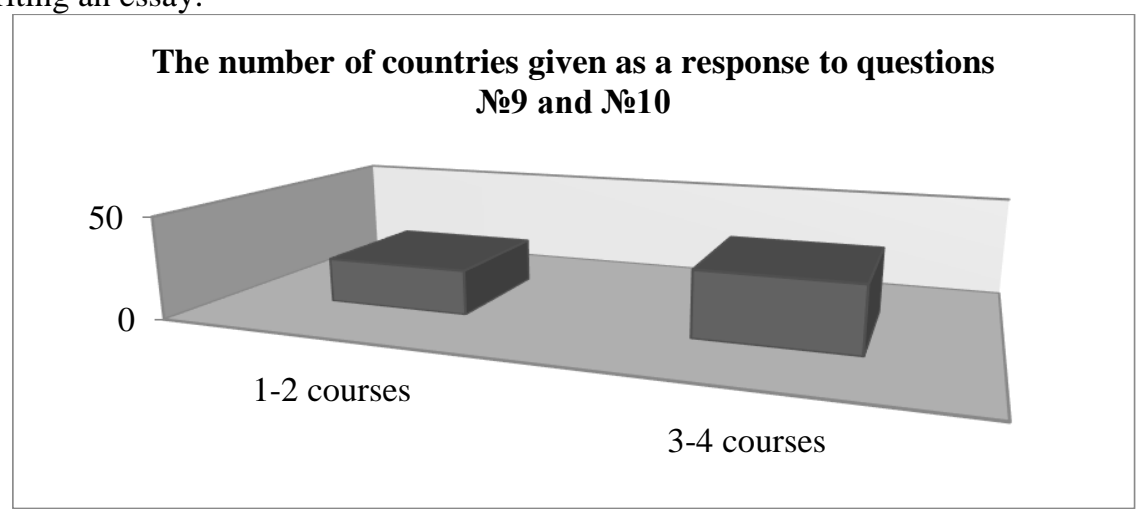

Fig. 3. The proportion of countries mentioned in response to questions №9 and №10 


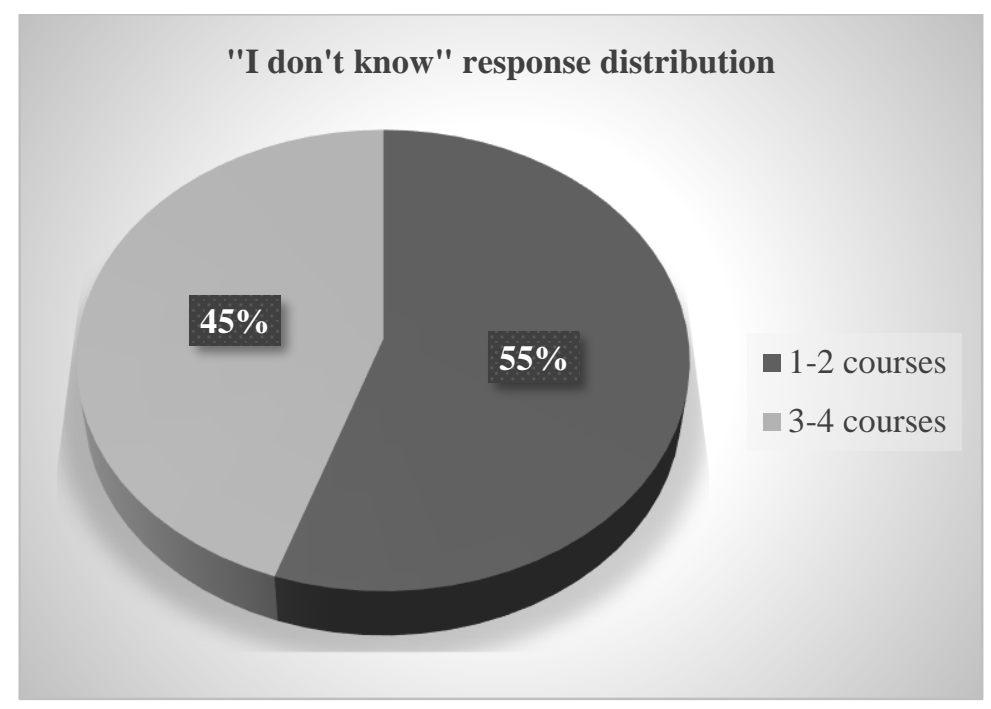

Fig. 4. The proportion of “I don’t know” responses to questions №9 and №10

\subsection{Project presentation}

Being one of the innovative technologies the project method helps to develop students' cognitive skills, the ability to think independently, apply creativity and initiative, put the problem and find solutions to it, navigate information space and be able to select information that is reliable, representative and relevant, the ability to process and analyze this media content, predict and evaluate the results of their work [7].

One of the advantageous characteristics of the project method over other educational technologies is that it helps to develop independent activity of students, individual or in groups, their analytical and creative skills and focus them on further research work.

One of the projects that the students of international relations and regional studies are offered to undertake is to create a prototype of an association of environmental ambassadors. The notion of an environmental ambassador is becoming quite popular. In the Internet resources we can find such expressions as environmental ambassador for sustainable development, green earth ambassador, ambassador for environment, green ambassador and the like. Though the notions sound synonymous the variety of them indicates that the goal of sustainable development or even sustainable lifestyle attracts more and more adherents nowadays.

On the preparatory stage students discuss possible spheres of focus of their project association, determine aims and tasks of the project, and define a number of participants of the group. On the second stage students work on the project, assign roles within it, plan, collect and analyze material, conduct research, and study the experience of real associations of this kind. The third stage is a demonstration of the project. The project of the association of environmental ambassadors may be presented in the form of a PowerPoint presentation in the class or students may create real pages in social media that will attract real followers and show real feedback of the audience. The final stage is assessment of the project and exchanging feedback when students share their impressions over the accomplished work, discuss their role and contribution to the project. 


\subsection{Role-play}

Role-play is a way of working through a situation, a scenario, or a problem by taking on roles and practising what to do in a safe setting [8]. This method of teaching facilitates a deeper involvement of the students in the educational process and develops their broader and more complex knowledge about an issue. Moreover, role-play increases students' interest and motivation, creates both emotional and intellectual attachment to the subject.

As one of the examples of application of this method we can point out that students receive a situation with a description of some ecological catastrophe in a particular region. They are to analyze it and list harmful impacts which will result from it, highlight possible worst-case scenarios of its consequences and categories of people affected. Students devise an action plan of short-term and long-term tasks, prioritize the most urgent ones, appoint responsible persons for tackling the problem. The roles assigned may vary from a high governmental level to local authorities and citizens as well as press and non-governmental organizations who in the form of a round table, conference or summit discuss a joint action plan, produce reasonable arguments and try to reproduce a real meeting and debate.

Such kinds of methods applied in teaching English places learners in a specific situation where they can take on different roles and accomplish specific tasks. Students may try themselves in taking responsibility for decision-making and develop their soft skills. Moreover, students themselves create a real communication situation where they can get plenty of opportunities to apply the vocabulary reviewed and learned in previous lessons, learn new lexical items, apply knowledge received at other subjects on international relations and regional studies, practise their diplomatic and negotiation skills. Authentic and spontaneous communication in quasi-realistic situations related to a future vocation not only allows students to practise a context-specific use of language, it animates the teaching and learning atmosphere, arouses the interest in studying and makes the whole process exciting. Students may also integrate their experience and their perspective into the construction of role-play situations, designing their own role-play cases [8].

\subsection{Writing a problem-solution essay}

It is worth mentioning that the material related to the areas of sustainable development and environment can be effectively applied in writing skills training. For this purpose, students write a problem-solution essay.

For example, at the English language lessons the following themes for writing an essay can be suggested:

- The threat to the Antarctic and protecting its environment.

- The threat of extinction of some animal species. The causes and effects.

- An environmental problem threatening a particular region.

- A natural disaster. Its causes and effects to a particular region.

- What does it mean to be an environmental ambassador?

This type of the task is aimed at teaching the skills of discussing a particular problem and presenting ideas to solve it. It forms the ability to analyze and synthesize information, produce arguments and details as well as teach basic essay writing skills, like its structure, useful phrases and cliches.

The syllabus for upper-division (3rd and 4th courses) students includes almost all above mentioned technologies with a more focus on analytical material, namely studying various scientific and other authoritative material related to the problems of international relations. Working with analytical articles students hold discussions about climate change and learn to look at it from different angles. They view it from the context of the transboundary nature of the challenges it poses and a threat multiplier. The potential insecurity caused by global 
warming deals with food and water availability, agricultural production, and population migration as one of the key linking points between climate change and armed conflict. We can clearly see that the chain of negative implications of climate change is becoming more complex and extensive creating higher risks to regional and global security. The transnational character of climate security challenges makes the states rely on intergovernmental organizations (IGOs), such as the European Union, the North Atlantic Treaty Organization (NATO) and the United Nations Environment Programme (UNEF). The issue is becoming so vital that traditional security organizations such as NATO and the UN Security Council include climate change actions into their agenda. The UN High Commissioner for Refugees (UNHCR) is expanding its work to address climate security challenges [10]. In this respect students of international relations and regional studies are taught not only the basic structural bodies and institutions of these IGOs but focus on specific matters that they are dealing with.

As role-play students organize summits on climate change, choose a country to be a representative of and present its stance on the issue and try to work out viable and effective policy solutions to mitigate climate change. For this purpose, they need to find supplementary material, analyze it and demonstrate a representative point of view that would reflect the country's policy. This task is quite interesting and challenging at the same time because as some authors say a great divide still exists among the countries and lack of basic trust [11]. So, the ability to present one's own arguments and be persuasive in this sometimes rather controversial issue will help students to form the skills that are very important for international relations specialists.

The students of the upper division quite often take part in various models of international organizations, namely Kazan UN Model, UNESCO Model and others. Such models are organized in a form of a conference and role-play and delegates work out the strategy of the country they represent, learn to make decisions on pressing issues and lobby their interests. Participants discuss real methods of addressing global challenges, take part in negotiations and draft resolutions. Today in many UN models there are committees devoted to the issues of environment and climate change. Sustainable development of the environment is included in the agenda of the models. For example, within the work of the UNHCR committee the theme of the discussion was devoted to environmental degradation and its impacts on refugees. Within the United Nations Committee on Science and Technology for Development the topic "Geoengineering: necessary to fight climate change or too risky" was raised. At the General Conference on the Future of the United Nations participants discussed how to modernize the United Nations Environment Programme. The Committee called the United Nations Framework Convention on Climate Change: COP 26 addressed the topic of bridging the global emissions gap.

It is worth mentioning the interest of our students to international forums. Online format gives a brilliant opportunity for future international relations specialists to participate practically in any event held by Russian and foreign universities and organizations. For example, the X Economic and Social Council (ECOSOC) Youth Forum held in April 2021 devoted almost half of its programme to the problems of ecology.

\section{Conclusion}

The increasing climate-related security risks that might include famine, destroyed infrastructure, houses and shelter and even armed conflicts that might all be consequences of climate change through gradual changes of ecosystems and extreme weather events attract the attention of a great variety of people representing educational, scientific, and political communities [11]. For future young professionals who study international relations and regional studies expertise in managing threats and risks emerging from climate change and variability is becoming important as this problem covers a great variety of issues. 
The main findings from the conducted questionnaire among students of Bachelor programmes in International Relations and regional studies and its in-depth analysis helped to outline the difference in the level of ecological awareness across lower-division and upperdivision university students. Generally, the results show that upper-division students are more ecologically conscious as they have acquired deeper knowledge of the problem and take active participation in thematic events. Empowerment through knowledge gives a better understanding of the mounting issues facing the world we live in, the importance of reduction of risks posed by climate change as well as the role of integrated governance for a just and legitimate adaptation to climate risks.

Thus, implementing ecology and climate change related topics in the syllabus of the educational programme of the Bachelor degree seems quite reasonable and topical. The overall process of English language teaching includes developing basic knowledge in the sphere of ecological awareness of lower-division (1st and 2nd year) students and further increasing complexity and involvement of upper-division (3rd and 4th courses) students. For these purposes the following forms of working with material are applied, namely various discussions, dialogues, brainstorming, problem-solution role-playing, project presentation, and writing an essay. The above-mentioned pedagogical technologies make the educational process natural and organic. They focus on independent activity of students, formation of creative, vocational and scientific skills. They all help to combine educational and research processes, make them more interesting and motivating for personal and professional development.

\section{References}

1. E.I. Szczepankiewicz, J. Fazlagi'c, W. Loopesko, Sustainability 14, 1241 (2021)

2. N.N. Maslennikova, I.I. Gibadulina, International Journal of Humanities and Cultural Studies July 2016, 519 (2016)

3. The Ecological Awareness - A Hope for Humanity and Contemporary Civilization, http://www.pulib.sk/web/kniznica/elpub/dokument/Bernatova6/subor/Smak.pdf

4. V.A. Hansen, A.A. Gostev, Psychological journal 10(2), 11 (1989)

5. E.I. Cherdymova, S.A. Afanasjeva, A.G. Parkhomenko, M.B. Ponyavina, E.S. Yulova, I.A. Nesmeianova, O.A. Skutelnik, Journal of BioSciences Eurasia J Biosci 12, 169 (2018)

6. The Greatest Threat to Global Security: Climate Change is not Merely an Environmental Problem http://www.un.org/en/chronicle/article/greatest-threat-global-security-climatechange-not-merely-environmental-problem

7. E.V. Krasilnikova, S.N. Kuznecova, On the formation of environmental consciousness among students of an agricultural university. IOP Conf. Ser.: Earth Environ. Sci. 723 04200. doi:10.1088/1755-1315/723/4/042006 (2021)

8. C. Schlegel, Role-Play in Teaching English. EALTHY. 27-29. (2018)

9. L. Dellmuth, M-T. Gustafsson, N. Bremberg, M. Mobjörk, Climate change and security (2018)

10. Swain, Ashok. Climate Change: Threat to National Security, 120053262 (2015)

11. L. Dellmuth, M-T. Gustafsson, N. Bremberg, M. Mobjörk, Wiley Online Library, 9(1) (2018) 